\title{
振動加速度の振幅変調を用いたセラミック加エエ具の損傷モニタリング*
}

\section{Damage Monitoring of Ceramic Grinding Tool Using Amplitude Modulation of Vibration}

\author{
Takumi INOUE*1 ${ }^{*}$, Toshiro EMURA and Takahiro NAKANO \\ ${ }^{* 1}$ Department of Mechanical Engineering, Faculty of Engineering, Kyushu University \\ 744 Motooka, Nishi-ku, Fukuoka, 819-0395 Japan
}

\begin{abstract}
One of the problems in ceramic grinding is damage to tool after a long time operation. It gives a crucial damage to work piece so that the grinding tool has to be replaced by new tool before the crucial damage. Acoustic emission is often used in the monitoring. It gives satisfactory results in certain case, while some results are ineffective because the acoustic emission is sensitive to noise. In the present study, we use the vibration acceleration of the ceramic work piece during the grinding process. The acceleration can be easily acquired and show stable characteristics irrespective of measurement location. We investigate a feasibility of damage monitoring of ceramic grinding tool using the vibration acceleration, and focus on the amplitude modulation of the obtained acceleration. A direct frequency analysis to the obtained acceleration is ineffective for the monitoring because it only shows broadband random frequency components. On one hand, the frequency analysis of the amplitude modulation shows significant results. The rotational frequency of the tool and its multiples are clearly observed in the frequency components of the amplitude modulation, and the tool condition can be monitored by tracking the transition of the rotational and its multiples frequency components.
\end{abstract}

Key Words : Monitoring, Diagnostics, Fault Detection, Signal Processing, Measurement

\section{1. 緒言}

セラミックは，ダイヤモンド砥粒を電着あるいは蒸着させた回転工具により研削加工される. 製品の概形を削 り出す工程は大型の自動機による連続運転で行われるが，長時間の加工を経ると砥粒が大きく脱落し，工具が破 損するとともにワークに損傷を与えることがある．ワーク損傷はコストに重大な影響を与えるため，適切な時期 で工具交換を行う必要があり, 工具状態を監視するモニタリング技術が要求される. モニタリングには, 加工を 中断して工具の状態を調べる直接法と, 加工中の動力, 振動, 音などから工具状態を推定する間接法がある. 自 動機による連続運転では間接法が望ましい. その方法として，セラミック研削ではアコースティック・エミッシ ヨン $(\mathrm{AE})^{(1)}$ を用いた研究が多く行われている. AEを用いた方法では, $\mathrm{AE}$ 信号の振幅や周波数スペクトルから 工具摩耗や研削状態が評価される(2)(3). また, 研削状態の正常／異常の評価・判定法として, いくつかの信号処理 手法との組みあわせも提案されている(4)-(6). しかしながら，破壊に伴う弾性波を検出する AE はノイズに敏感で あり，適切な位置に $\mathrm{AE}$ センサを設置しないと有効な信号が得られないことが指摘されている(7). $\mathrm{AE}$ 以外の間接 法として, 研削時の音響データの利用 ${ }^{(8)}$, 工具近傍での潤滑液圧力の利用 ${ }^{(9)}$ などの試みも報告されているが, 一 般的手法として確立されるには至っていないように思われる.

これに対し本研究では, 比較的容易かつ安定に測定できる振動加速度を用いたセラミック研削工具のモニタリ ングを試みる。ここではワークピース側の加速度を対象とする．振動加速度データを用いたモニタリングにはエ ンドミル ${ }^{(10)} や ト ゙ リ ル^{(11)} の 工$ 具摩耗の例があり, このような切れ刃が明確な工具の場合, 加速度中に現れる工具回

* 原稿受付 2012 年 7 月 24 日

*1 正員, 九州大学大学院工学研究院（下819-0395 福岡県福岡市西区元岡 744 番地）

*2 正員, 九州大学大学院工学府

E-mail: takumi@mech.kyushu-u.ac.jp 
転速度の倍数成分が工具損傷に関する重要な情報を与えることが知られている．しかしながら，セラミック研削 では，砥粒で覆われた工具表面は砥粒の大きさや配置が不規則なため計測される振動加速度も不規則となり，周 波数解析を行っても工具の回転数成分を見出すことができない，そのため，セラミック研削のモニタリングに振 動加速度が用いられる例は少なく, 切削力や $\mathrm{AE}$ と併用した例(12)が見られる程度である，一方，本研究では，測 定された振動加速度そのものは不規則であるものの, 振動加速度の包絡線に工具回転数に関連寸る成分が包含さ れていることを見出した，そこで，この包絡線の変化，すなわち振幅変調に着目することで工具状態のモニタリ ングを行う方法を提案する. 振幅変調（包絡線）の計算にはヒルベルト変換を用い，振幅変調の周波数解析によ り回転数に関連した周波数成分が上手く抽出されることを示す. 研削加工の進行にあわせてそれらの成分を追跡 すると, 工具損傷の前段階で，工具回転数成分とその倍数成分の相対的な関係が変化することがわかった. すな わち, 提案した手法が, 工具摩耗状態の推定や工具損傷の予測に有効であることを示寸.さらに, 本研究で実施 した研削実験では, 測定場所による振動特性の差異がほとんどなくセンサ設置位置の自由度が大きいこともわか った.このことも提案した手法の優れた点である.

\section{2. セラミック研削と工具損傷}

\section{$2 \cdot 1$ セラミック研削}

セラミックには様々な種類があり, アルミナ, 炭化ケイ素, 窒化ケイ素などをはじめ多くの材質が知られてい る. 中でもアルミナはよく用いられるセラミック材料であり比較的軟らかいことで知られる. 図 1 はアルミナセ ラミック研削の概略であり, 自動機による側面研削 (Side face grinding), 上面研削 (Surface grinding), 穴あけ

(Drilling) 等により外形を形成する. 研削にはダイヤモンド砥粒が蒸着された円筒形の回転工具が用いられる. 側面研削と表面研削では工具は主に工具軸方向と直角に送られ，アルミナセラミックは軟らかいため，連続的な 送り（連続研削）が可能となる. 一方, 穴あけは, 切りくずの排出等の問題から連続研削は難しく, 工具を少し ずつ軸方向に進める断続研削が行われる，連続研削ではワークピースはほぼ安定的に振動するが，断続研削では 工具とワークピースの接触状態が断続的に変化するため, 振動は連続研削ほど安定ではない. 著者らは, 本研究 を加速度利用によるセラミック研削工具モニタリングの基礎研究と位置づけており，ここでは安定した振動特性 が得られる連続研削，すなわちアルミナセラミックの側面研削と表面研削を対象とする. 図 2(a)に直径 $20 \mathrm{~mm} の$

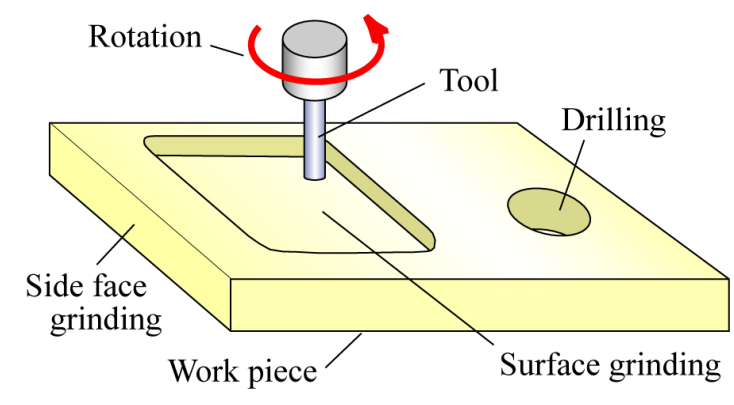

Fig.1 Grinding of alumina ceramic
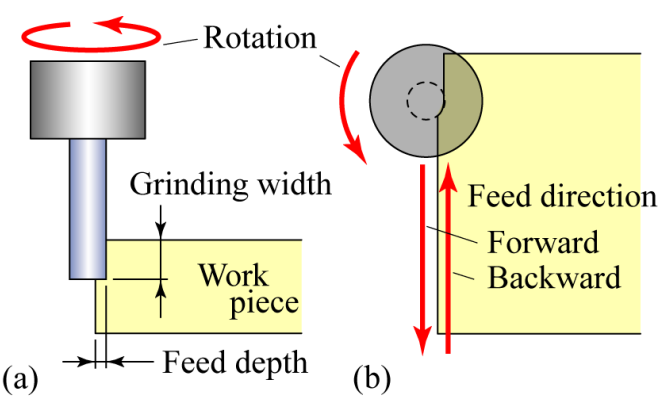

(b)

Fig.3 Sketch of side face grinding, (a) front view and (b) top view.

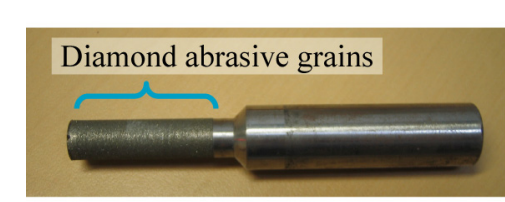

(a)

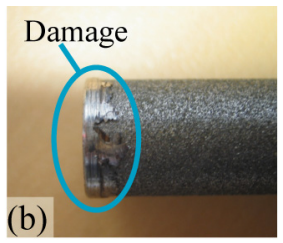

Fig.2 Grinding tool with a diameter of $20 \mathrm{~mm}$, (a) overview and (b) crash damage to tool occurred in surface grinding.

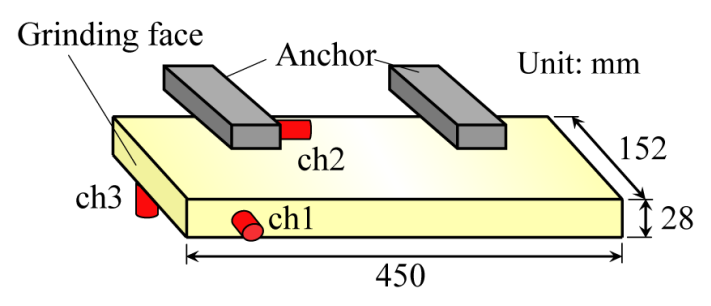

Fig.4 Location of accelerometers. 
Table 1 Side face grinding tests using a cylindrical tool with a diameter of $20 \mathrm{~mm}$.

\begin{tabular}{|c|c|c|c|c|c|c|}
\hline Test & $\begin{array}{c}\text { Grinding } \\
\text { width }(\mathrm{mm})\end{array}$ & $\begin{array}{c}\text { Feed depth } \\
(\mathrm{mm} / \mathrm{stroke})\end{array}$ & $\begin{array}{c}\text { Rotational } \\
\text { speed (rpm) }\end{array}$ & $\begin{array}{c}\text { Feed speed } \\
(\mathrm{mm} / \mathrm{min})\end{array}$ & Stroke & Note \\
\hline 1 & \multirow{3}{*}{28} & 0.1 & \multirow{3}{*}{8000} & \multirow{3}{*}{880} & 30 & \multirow{3}{*}{$\begin{array}{l}\text { Feed speed increased at } 10 \% \text { per } \\
\text { stroke. Damage to tool occurred at the } \\
29 \text { th stroke in test } 3 \text {. }\end{array}$} \\
\hline 2 & & \multirow{2}{*}{0.2} & & & 15 & \\
\hline 3 & & & & & 29 & \\
\hline
\end{tabular}
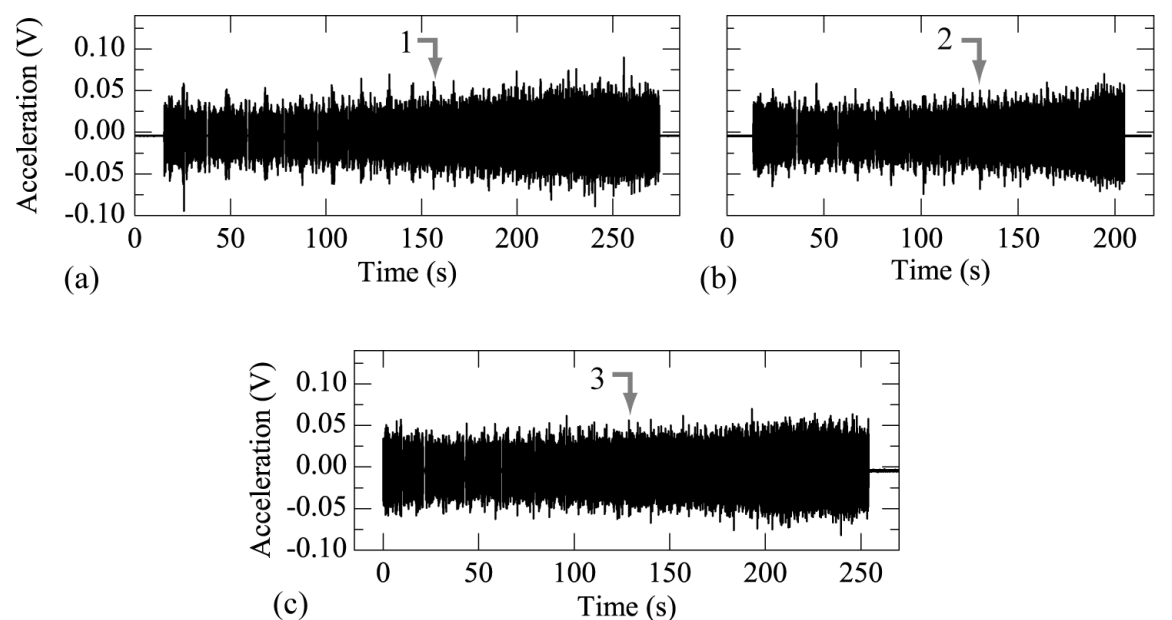

Fig.5 Acceleration during side face grinding in (a) test 1, (b) test 2 and (c) test 3.

工具を示す．円筒部側面と端面にダイヤモンド砥粒が蒸着されており，この部分で研削を行う．図 2(b)には上面 研削により破損した同種の工具を示す．円筒端部のダイヤモンド砥粒が脱落していることがわかる.

\section{$2 \cdot 2$ 側面研削実験と通常の周波数解析}

まず，図 2(a)に示した直径 $20 \mathrm{~mm}$ の工具による側面研削を行う. 図 3 に側面研削の概略図を示す. 図 3(a)正面 図（Front view）に示すように, 指定された研削幅（Grinding width）, 送り深さ（Feed depth）に従って研削され, 図 3(b)上面図（Top view）に示すように，セラミック側面を工具が往復して研削する. 研削 1 行程（Stroke）は往 き（Forward）および帰り（Backward）の両方向で実行される. アルミナセラミックのワークピースは図 4 に示す 板状であり，図 4 左側端面を連続的に研削した. 加速度ピックアップは，図 4 に示す 3 箇所 $(\operatorname{ch} 1 〜 \operatorname{ch} 3)$ で測定 した. ch1〜 ch3 の向きはそれぞれ直交している. ch1, ch3 はワークピースに直接加速度ピックアップを接着剤で 貼り付けた。このような測定は実用上適切ではないが，工具状態の変化を確実に捉えるため，できるだけ研削部 に近い場所での加速度の測定を意図とした. ch2 の加速度ピックアップは, 現実的な場所として図 4 に示すワー クピースを固定する固定具 (Anchor) に取り付けた. サンプリング周波数は $5 \mathrm{kHz}$ とした. 研削中の振動加速度 を測定した結果， ch1〜 ch3 の加速度は測定感度がやや異なるもののほぼ同様の振動特性を示し，結果的に 1 つに 着目すれば十分であることがわかった，以後，実用上問題ない測定場所である ch2 の測定結果を対象とする.

研削実験は同じ工具を用いて 3 回行った。それぞれの実験を実験 1 （Test 1）～実験 3（Test 3）と呼ぶ. 工具は 実験 3 の途中で破損した. 各実験条件を表 1 に示寸. 送り深さ（Feed depth）は 1 回の行程で切り込む深さ, 送り 速度（Feed speed）は送り方向（Feed direction）の速度である. 通常の研削条件では工具破損までに長い時間を要

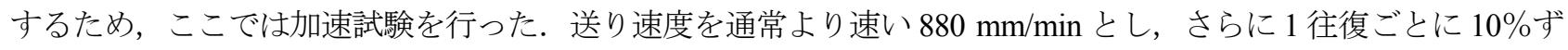
つ増加する設定にした. 実験 1,2 では工具は破損せず，実験 3 の 29 往復目で工具が火花を発して破損し，その時 点で実験を終了した. 実験 1〜3 で測定した加速度をそれぞれ図 5(a), (b), (c)に示す. 図 5 から, 時間が進むにつ れ送り速度が速くなり 1 行程の時間が短くなっていることがわかる. 実験 3 の 29 行程目（時間 250 秒付近）で工 具が破損した.

本研究では加速試験により通常より早く工具を破損させた. 加速試験による工具損耗を通常の加工と同等に見 なすことは以下の理由で妥当と考えている. これまでの研究から, 送り速度や研削量の増加に対し, ワークピー 

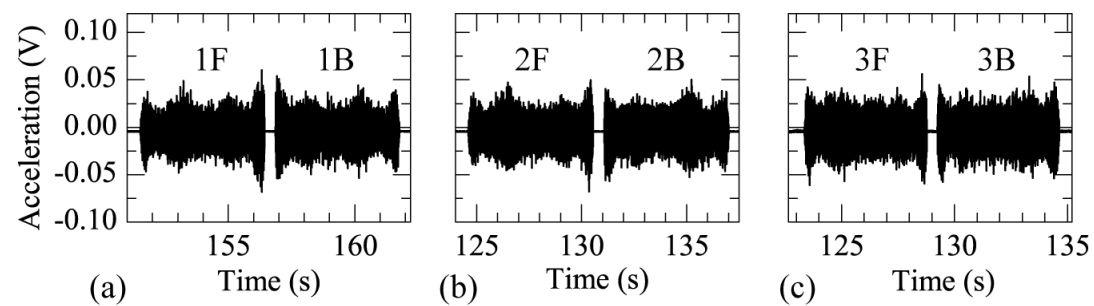

Fig.6 Enlarged view of acceleration, (a) test 1, (b) test 2 and (c) test 3.
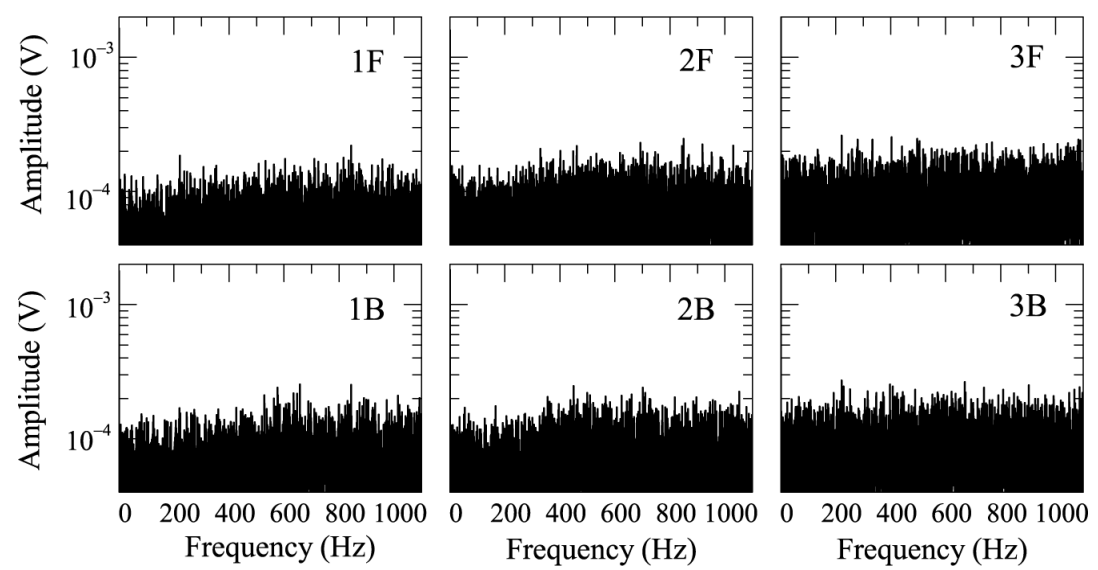

Fig.7 Frequency analyses of acceleration during side face grinding.

スの研削表面は若干悪化するものの大きな変化はないことが知られている(13)(14)，これは砥粒の脱落がスムーズに 促進されて工具抵抗の増加を緩和しているためと考えられている．このことは，図 5 において送り速度の増加ほ ぞ振動加速度は増加していないことからも推測できる. 送り速度の増加に対しては, 極端に大きな研削抵抗に起 因寸る損傷など，通常と異なる原因による工具損耗の発生は抑えられている。したがって，本研究で実施した加 速試験における工具損傷は, 損傷に至るまでの時間は短縮されるものの通常研削の工具損傷とほぼ同様の形態で 発生したと思われ，モニタリングの対象として妥当である.

一方，機械加工においては，びびり振動のような自励振動の問題が存在することも知られている ${ }^{(15)}$. 自励振動 は振動系の固有振動数で発生する.これに対し, 本研究で用いた自動機は剛性が高く, 片持ちはり状の研削工具 部分の固有振動数は数 $\mathrm{kHz}$ 程度であることを確認している. 固定されたワークピース側の岡性はさらに高く，固 有振動数も同様に高い. 本研究では工具回転数成分とその倍数成分に着目寸るが, 回転数は百数十 $\mathrm{Hz}$ 程度（表 1 の実験では 8000 rpm=133 Hz）であることを考えると，自励振動の影響は考慮しなくても差し支えない.

各実験の中間部分に相当寸る，図 5(a), (b), (c)中において矢印で示した 1,2,3 の部分の拡大図を図 6(a), (b), (c) に示寸. 図 6 には工具 1 往復分に相当する加速度波形が示されており, 図 6(a)の往きの研削に相当する加速度を $1 \mathrm{~F}$ ，帰りの研削に相当する加速度を 1B と記す. 同様に，図 6(b)および(c)の往き，帰りの加速度を，それぞれ $2 \mathrm{~F}$, 2B および $3 \mathrm{~F}, 3 \mathrm{~B}$ と記す. 研削が行われている所で加速度が大きくなっている. これらの振動加速度にフーリエ 変換を適用した周波数解析結果を図 7 に示寸. 図 6 の部分波形 $1 \mathrm{~F}, 1 \mathrm{~B} \sim 3 \mathrm{~F}, 3 \mathrm{~B}$ の周波数解析結果が, それぞれ図 7 の $1 \mathrm{~F}, 1 \mathrm{~B} \sim 3 \mathrm{~F}, 3 \mathrm{~B}$ に対応する. 横軸は周波数, 縦軸は各周波数成分の大きさを表す. 表 1 に示すように，この
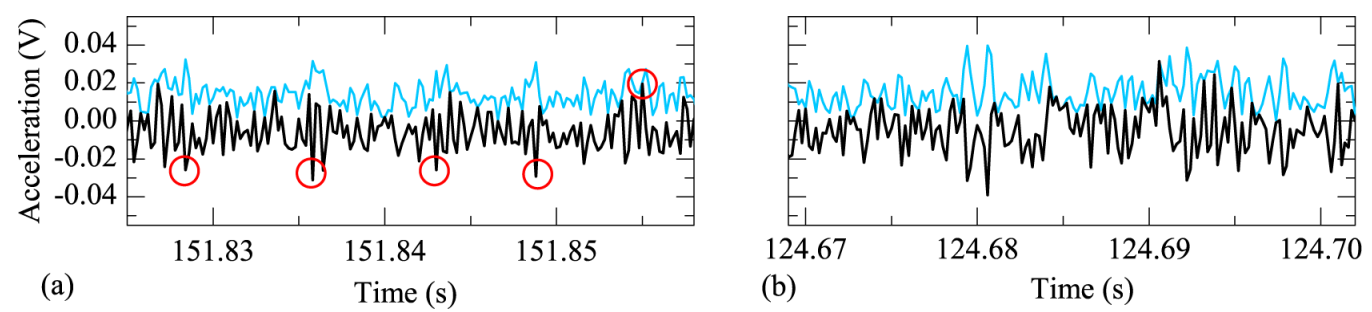

Fig.8 Detail view of acceleration and envelop curve, (a) $1 \mathrm{~F}$ in test 1 and (b) $3 \mathrm{~F}$ in test 3. 
実験の工具回転数は $n=133 \mathrm{~Hz}(8000 \mathrm{rpm})$ であるが，133 Hzおよびこの倍数成分は図 7 には明確に現れておら ず，ほぼ一様に周波数成分が存在している．加工は $(1 \mathrm{~F}, 1 \mathrm{~B}) \rightarrow(2 \mathrm{~F}, 2 \mathrm{~B}) \rightarrow(3 \mathrm{~F}, 3 \mathrm{~B})$ となるにつれ進行するが，それ にともなう振動数成分の変化等を見出すことはできない. したがって, 測定した振動加速度に対する通常の周波 数解析では工具損傷のモニタリングができないことがわかる.

ここで, 加速度波形 $1 \mathrm{~F}$ と $3 \mathrm{~F}$ の一部の拡大図を図 $8(\mathrm{a})$ と 8(b)にそれぞれ示寸. 図中の黒の実線が加速度波形を 表している．1F, $3 \mathrm{~F}$ ともに不規則な振動の様相を示しているが，1F では赤印で示寸位置で振幅がほぼ一定の周期 ごとに大きくなっていることが見て取れる，一方，3F ではそのような規則性は認められない．さらに，図 8(a)の 赤印の周期は工具回転数の周期 $7.5 \mathrm{~ms}(133 \mathrm{~Hz})$ に近い值である. 図 8(a) と 8(b)の違いは, 加速度振幅の包絡線に 着目すれば明確に現れると思われる.つまり, 加速度振幅の包絡線の変化から工具状態のモニタリングが実現で きる可能性がある. そこで, 振動加速度の包絡線, すなわち, 振幅変調に着目したモニタリングを試みる. 本研

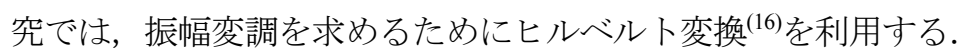

\section{3. ヒルベルト変換による振幅変調解析}

\section{$3 \cdot 1$ ヒルベルト変換}

$u(t)$ を連続な実関数とすると, $u(t)$ のヒルベルト変換 $h(t)$ は次式で定義される.

$$
h(t)=\frac{1}{\pi} \int_{-\infty}^{\infty} \frac{u(s)}{t-s} d s
$$

$h(t)$ は $u(t)$ の振動数成分の位相を $90^{\circ}$ シフトさせた信号になる. 実際に測定する超音波波形 $u(t)$ は離散データで あり, その場合のヒルベルト変換は式(1)ではなく, $u(t)$ の離散フーリエ変換 $\hat{u}(\omega)$ に対し，

$$
\hat{z}(\omega)=0 \quad(\omega<0), \quad \hat{z}(\omega)=\hat{u}(\omega) \quad(\omega=0), \quad \hat{z}(\omega)=2 \hat{u}(\omega) \quad(\omega>0)
$$

の操作を行い, $\hat{z}(\omega)$ を離散逆フーリエ変換して求めた $z(t)=u(t)+i h(t)(i$ は虚数単位 $)$ の虚部として得られる. 時間の関数として表される振幅 $A(t)$ （振幅変調）は，次式から求められる.

$$
A(t)=\sqrt{u(t)^{2}+h(t)^{2}}
$$

例として, 図 8 の振動加速度に対してヒルベルト変換を適用して求めた振幅（振幅変調）を図中の水色の線で示 寸. 振幅変調は, 図 8(a)に示寸加速度波形 $1 \mathrm{~F}$ では図中の赤印と同期してある程度規則的に変化しているのに対し, 図 8(b)の加速度波形 $3 \mathrm{~F}$ では規則性が見られない. 次節以降では振幅変調の周波数解析を行い, その周波数成分の 変化から工具状態のモニタリングが実現できるかを検証する.

\section{$3 \cdot 2$ 側面研削時の振動加速度の振幅変調}

2 章で行った直径 $20 \mathrm{~mm}$ の工具による側面研削の実験結果に対して振幅変調の周波数解析を行う．まず，図 6 に示した部分波形 $1 \mathrm{~F}, 1 \mathrm{~B} \sim 3 \mathrm{~F}, 3 \mathrm{~B}$ にそれぞれヒルベルト変換を適用して振幅変調を求め, 各振幅変調にフーリエ 変換を適用して周波数成分を求める. 図 6 の部分波形 $1 \mathrm{~F}, 1 \mathrm{~B} \sim 3 \mathrm{~F}, 3 \mathrm{~B}$ に対寸る結果を, それぞれ図 9 の $1 \mathrm{~F}, 1 \mathrm{~B}$ $\sim 3 \mathrm{~F}, 3 \mathrm{~B}$ に示寸. 図 9 から, 実験 1 での加速度 $1 \mathrm{~F}, 1 \mathrm{~B}$ では, 工具の回転数成分 $n=133 \mathrm{~Hz}$ が明確に現れており, 実験 2 の $2 \mathrm{~F}, 3 \mathrm{~B}$, 実験 3 の $3 \mathrm{~F}, 3 \mathrm{~B}$ と進むにつれ回転数成分 $n$ が小さくなっている. また, $3 \mathrm{~F}, 3 \mathrm{~B}$ では $2 n$ 成分が現 れている. このように, 振動加速度の振幅変調に対する周波数解析を行うと, 工具の回転数に関連する成分が取 り出せることが示される.

この結果を踏まえ, 実験 1 から実験 3 までのすべての研削行程について, 振幅変調の工具回転数成分 $n=133 \mathrm{~Hz}$ とその 2 倍成分 $2 n=266 \mathrm{~Hz}$ を図 10 に示寸. $1 \mathrm{~F}, 1 \mathrm{~B} \sim 3 \mathrm{~F}, 3 \mathrm{~B}$ と同様, 各研削行程の往き・帰りの部分波形を対象 とした. 図 10 の横軸は研削行程（Stroke）を示し，研削 1 行程は工具の往きと帰りからなるため, 横軸は 0.5 刻 みでデータを表示している. つまり, 往き, 帰り, 往き...の行程が横軸の $0.5,1.0,1.5 \ldots$ 等に相当する. また, 図 10 は実験 1 から実験 3 までの寸べての行程を通算して示しており,横軸の行程は実験 1 から実験 3 までの通算 

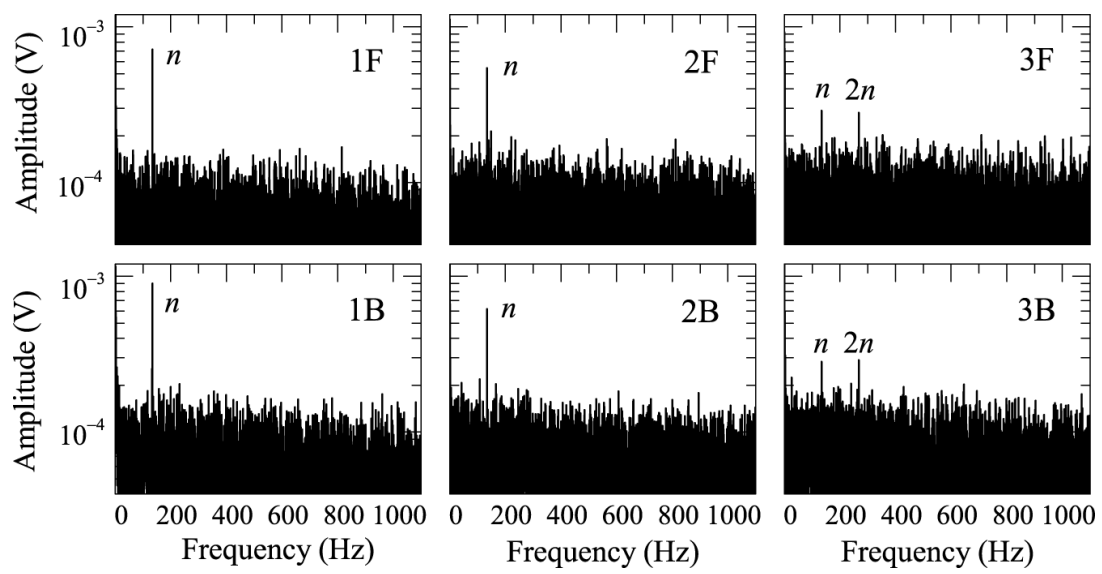

Fig.9 Frequency analyses of amplitude modulation of acceleration during side face grinding.

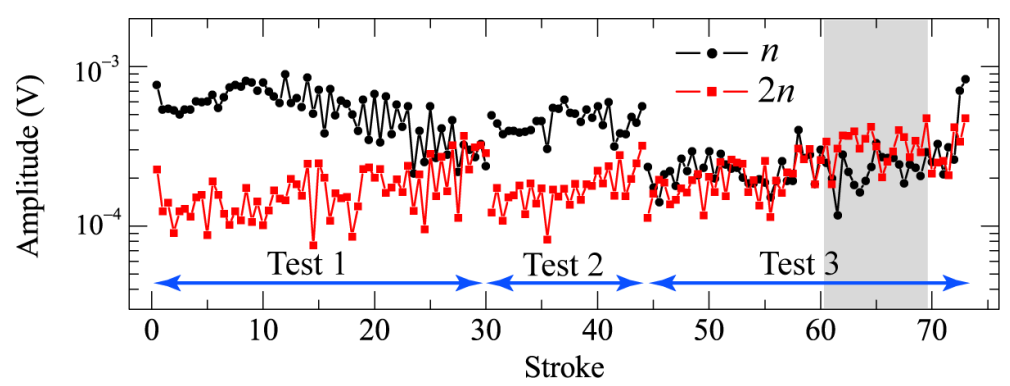

Fig.10 Transition of frequency components of $n$ and $2 n$ in amplitude modulation of acceleration during side face grinding.

の值を表す. 寸なわち, 行程 1〜30 が実験 1, 行程 31〜 45 が実験 2, 行程 46〜 74 が実験 3 に相当する. 縦軸は振 幅変調の $n$ と $2 n$ 成分を示す.

図 10 の実験 1 の部分では, 実験開始時に大きな值を示した $n$ 成分が，増加，減少を繰り返しながらも全体的に 低下している. 一方， $2 n$ 成分は，上下に変動しながらも徐々に増加している. 実験 2 の部分では $n$ 成分はやや回 復し，増加，減少を繰り返すが平均的には大きな変化は示さない. $2 n$ 成分は実験 2 開始時に低下寸るが，再び増 加傾向を示す. 実験 3 になると, 開始時には $n, 2 n$ 成分ともに小さくなるが，その後両成分ともに増加し，図中の 網かけで示寸 $60 \sim 70$ stroke あたりで $2 n$ 成分が $n$ 成分をほぼ逆転している. その後, 数 stroke で工具破損に至る. この結果から, 研削が進むにつれて $n$ 成分は減少する方向にあり, 逆に $2 n$ 成分は増加する方向にあることがわか る. また, 工具破損の少し前で, 網かけ部のように $2 n$ と $n$ の相対的な関係が逆転し，ここでは工具が厳しい状態 にあると推測できる．同様の現象は別の実験でも確認できた．したがって，ここで実施したアルミナセラミック の側面研削では, 測定した振動加速度の振幅变調において工具の回転数成分 $n$ とその 2 倍の $2 n$ の成分を追跡して いくことで，工具損傷のモニタリングが概ね可能といえる. なお，図 4 に示した $\operatorname{ch} 1$ と $\operatorname{ch} 3$ の加速度ピックアッ プで測定したデータについては, ワークピースの振動を直接測定しているため $n, 2 n$ 成分の感度は高い. ただし, 互いの相対的な関係は図 10 とほぼ同一であった.このように, 振動加速度を用いると測定位置に影響されず安定 したモニタリングが実現できる.このことも提案した手法の優れた点である.

工具表面には砥粒による不規則な凹凸があり, 研削により発生する振動はほぼランダムとなる，そのため，研 削時の振動加速度をそのまま周波数解析した結果は図 7 のように広範囲な振動数成分を示す. 一方, 円柱状の工 具は, 表面の凹凸に加え図 11(a)のようにわずかに偏心して回転していると思われる.これにより振動加速度に回 転数に等しい振幅変調が生じ，これをヒルベルト変換が捉えたと考えられる. その後, 研削加工が進むにつれ, 図 11(b)のように偏心や表面の凸部が工具摩耗により小さくなることで振幅変調の回転数成分 $n$ が減少する.さら に, 図 11(c)のように工具の一部に比較的大きな摩耗, 砥粒の脱落などの小さな損傷が生じることで, 振幅変調に 回転数の 2 倍数成分が生じ始めると思われる. 砥粒の脱落は連続, 一様に起こらないため, 図 11 の変化も連続的 でなく $n$ および $2 n$ 成分は細かく増減しながら变化する. これらを繰り返し, 最終的には $2 n$ 成分が相対的に $n$ 成 


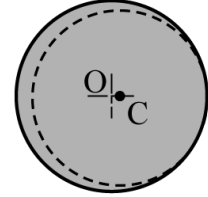

(a)

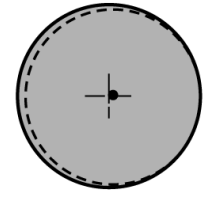

(b)

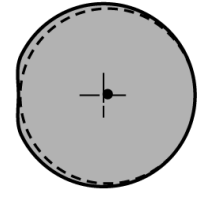

(c)

Fig.11 Conception diagram of wear and damage to tool.

(a)
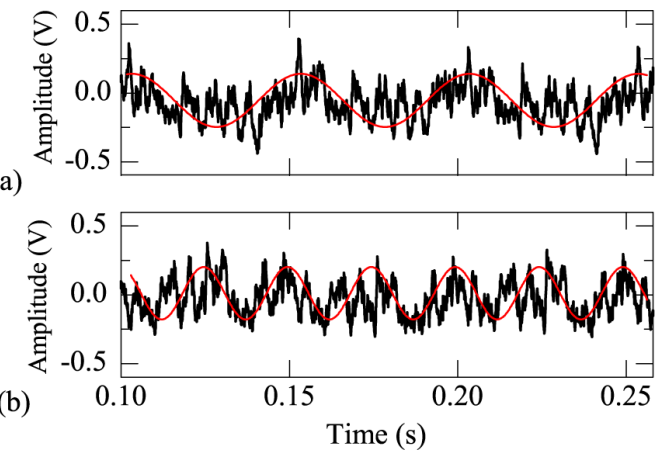

Fig.12 Surface of tool after crash damage to tool, (a) non-damaged part and (b) damaged part.

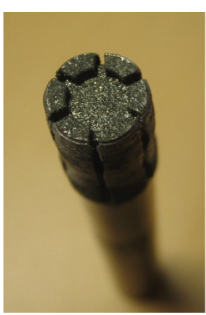

(a)

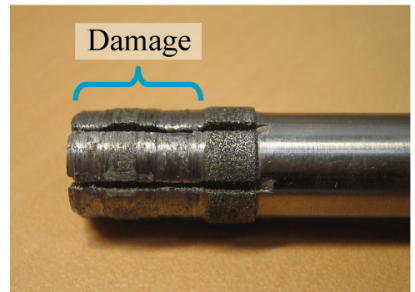

(b)
Fig.13 Grinding tool with a diameter of $9 \mathrm{~mm}$, (a) tool edge divided into 6 blocks and (b) crash damage to tool occurred in surface grinding.

分より大きくなる程度に成長すると工具が大きなダメージを受ける時期に至ったと考えられる．このことを間接 的ではあるものの検証するために，損傷した工具を旋盤に取り付けて回転させ，工具表面の振動をレーザードッ プラー振動計で計測して表面形状の概形を調べた. 工具の回転数は $20 \mathrm{~Hz}$ とした. 工具の非加工部（非損傷部） の結果を図 12(a)に，加工して損傷した部分の結果を図 12(b)に示寸．図の横軸は時間，縦軸は計測された速度に 相当する電圧を示す.旋盤への取り付けにも若干の偏心があると思われ, 図 12(a)の非加工部は回転数成分の $20 \mathrm{~Hz}$

（周期 $0.05 \mathrm{~s}$. 赤で示寸振動）が主であることがわかる. 一方, 図 12(b)の損傷部では, 回転数の 2 倍成分（赤で 示寸振動）が大きいことが確認でき，図11(c)のような損傷状態が推測できる.

\section{$3 \cdot 3$ 工具形状の振幅変調への影響}

次に, 図 13 に示すような端部がいくつかのブロックに分かれている工具による同様の側面研削を行う. 工具直

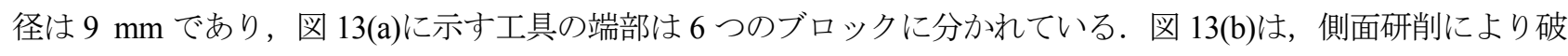
損した状態を示す. このような形状の工具についても，振幅変調の周波数解析により工具状態のモニタリングが 可能であるか調査する. 側面研削の実験は図 3 と同様であり, 表 2 に研削条件を示す. 通常の加工より送り速度 が大きい加速試験としての条件である. 1 回の実験につき 10 往復の研削を行い, 3 回目の実験の 9 往復目で工具 が破損した．実施した 3 回の実験（実験 4〜6 と呼ぶ）の振動加速度をそれぞれ図 14(a), (b), (c)に示す. 実験によ り送り速度が異なるため, 横軸（時間軸）のスケールが異なることに注意されたい. 図 14(c)に示すように, 実験 3 の 9 往復目で振幅が大きくなり，ここで工具が破損した。 この実験に限れば破損直前の $7 \sim 8$ 往復目で振幅が増 加していくため, 振幅の観察から工具損傷の予測も可能であるが, 3.2 節に示した振幅変調によるモニタリングが, 形状の異なる工具に対しても有効であるかを確認する.

図 14 に示した波形中, 3 つの往復部分を新たに $4 \mathrm{~F}, 4 \mathrm{~B} \sim 6 \mathrm{~F}, 6 \mathrm{~B}$ と指定する. これらの部分波形に対し，ヒルベ ルト変換とフーリエ変換を用いた振幅変調の周波数解析を図 15 に示寸. 実験 4 および実験 5 の部分波形 $4 \mathrm{~F}, 4 \mathrm{~B}$

Table 2 Side face grinding tests using a cylindrical tool with a diameter of $9 \mathrm{~mm}$ and divided edge.

\begin{tabular}{|c|c|c|c|c|c|c|}
\hline Test & $\begin{array}{l}\text { Grinding } \\
\text { width (mm) }\end{array}$ & $\begin{array}{l}\text { Feed depth } \\
(\mathrm{mm} / \text { stroke })\end{array}$ & $\begin{array}{c}\text { Rotational } \\
\text { speed (rpm) }\end{array}$ & $\begin{array}{c}\text { Feed speed } \\
(\mathrm{mm} / \mathrm{min})\end{array}$ & Stroke & Note \\
\hline 4 & \multirow{3}{*}{10} & \multirow{3}{*}{0.2} & \multirow{3}{*}{6000} & 800 & \multirow{2}{*}{10} & \multirow{3}{*}{$\begin{array}{l}\text { Tool failure occurred at the 9th stroke } \\
\text { in test } 6 .\end{array}$} \\
\hline 5 & & & & 1200 & & \\
\hline 6 & & & & 1600 & 9.5 & \\
\hline
\end{tabular}



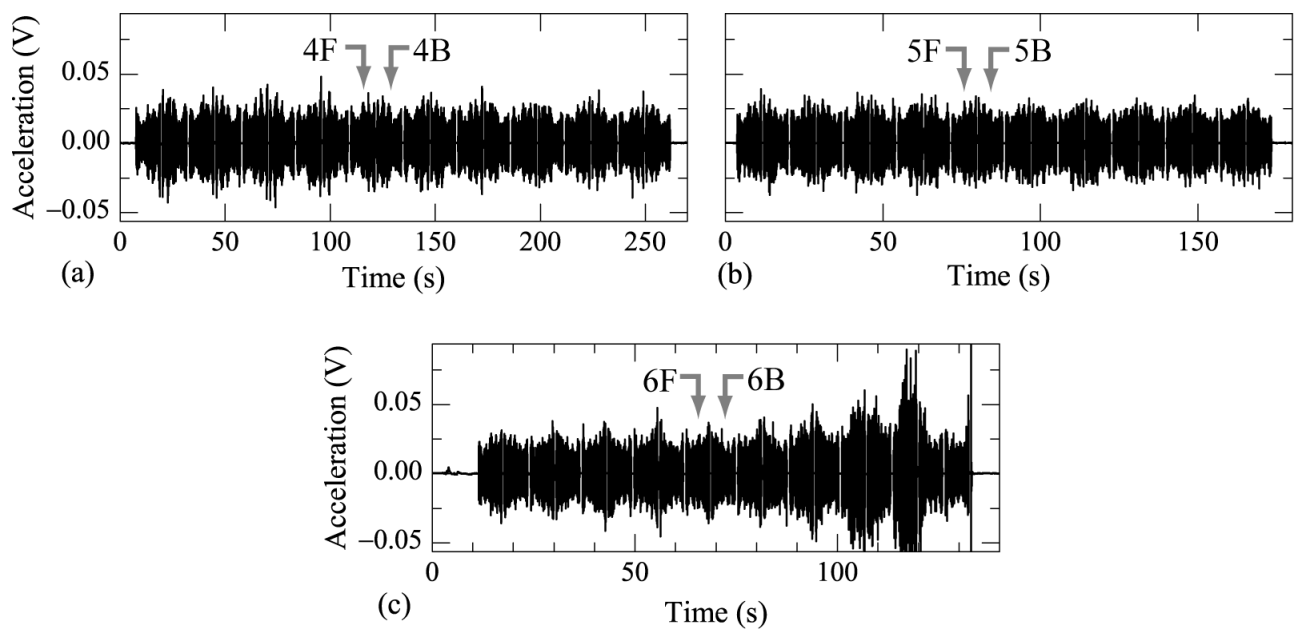

Fig.14 Acceleration during side face grinding using a cylindrical tool with divided edge in (a) test 4, (b) test 5 and (c) test 6 .
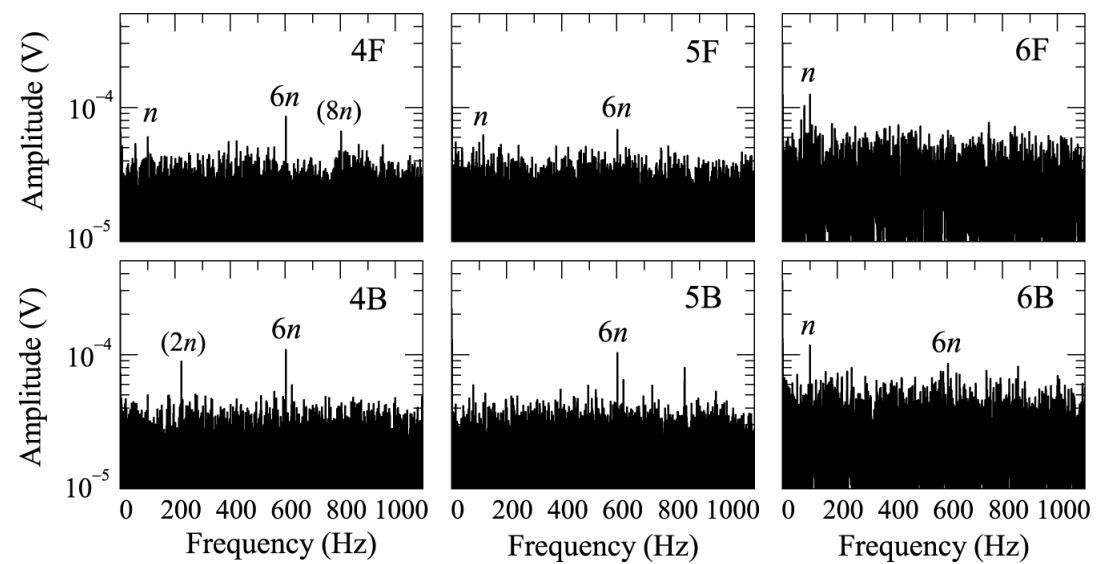

Fig.15 Frequency analyses of amplitude modulation of acceleration during side face grinding with a cylindrical tool with divided edge.

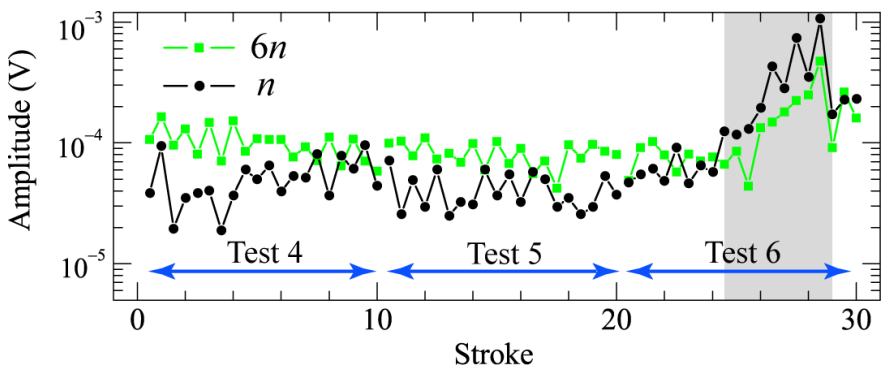

Fig.16 Transition of frequency components of $n$ and $6 n$ in amplitude modulation of acceleration during side face grinding with divided edge.

および $5 \mathrm{~F}, 5 \mathrm{~B}$ の振幅変調では，回転数成分 $n=100 \mathrm{~Hz}(6000 \mathrm{rpm})$ の 6 倍である $6 n=600 \mathrm{~Hz}$ の成分が大きい. こ れは，工具の端部が 6 ブロックに分かれている影響と考えられる． $6 n$ 以外にも， $4 \mathrm{~F}$ では $n, 8 n, 4 \mathrm{~B}$ では $2 n$ の成 分も確認できる, 実験 5,6 と加工が進むにつれ， $6 n$ 成分が相対的に小さくなり回転数成分 $n$ が大きくなってい る.このように, 図 13 に示すような端部がブロックに分かれている工具では, 振幅変調には回転数成分に加え様々 な倍数成分が観測されることがわかる． 4F, 4B 〜 6F, 6B 以外の部分波形の振幅変調を詳細に調べた結果，加工の 進行に伴い有意な変化を示寸振動数成分は $n$ と $6 n$ であることがわかった. そこで, 実験 $4 \sim 6$ 全体に渡る $n$ と $6 n$ 成分の変化を図 16 に示寸. 図 10 と同様, 研削 1 行程の往き・帰りそれぞれの部分波形を対象とした. 横軸は実 験 4 6 を通じた研削行程であり 0.5 刻みで表示している. 実験 $4 ， 5$ では $6 n$ 成分は $n$ 成分よりおよそ大きな值を 示寸が, 実験 6 になると, 24 stroke 付近から $n$ 成分が急激に大きくなり, 網かけで示した部分で $6 n$ 成分と大きさ 
が逆転した後，工具破損につながっていることがわかる．したがって，ここで用いた端部が数個のブロックに分 割された形状の工具でも, 振動加速度の振幅変調から工具回転数成分とその倍数の成分が求められ, それらの変 化から工具状態がモニタリングできることがわかる．ただし，回転数成分 $n$ に加え，回転数 $\times$ ブロック数の成分 (ここでは工具の端部が 6 ブロックであることから $6 n$ ) が重要となる.

振幅変調に工具回転数成分とその倍数の成分が表れるメカニズムは図 11 と類似であると思われる.ただし，こ こで用いた工具では端部が分割されている影響が偏心等の影響より大きく, 実験開始時は $6 n$ 成分が顕著に表れて いる. 研削が進行して一部に比較的大きな脱落が生じると，それにより偏心と同様の影響が現れることで $n$ 成分 が増大し, 振幅変調に変化が現れたと考えられる. モニタリングの対象として着目すべき振幅変調の成分と, そ れらの間の相対的な関係は工具形状に依存することに注意が必要である.

\section{$3 \cdot 4$ 上面研削時の振動加速度の振幅変調}

上面研削 (図 1 参照) に対しても振動加速度の振幅変調が工具モニタリングに対して有効であるかを調べる. 図 2 と同種で, 端部が直径 $10 \mathrm{~mm}$ の工具を用いて上面研削を行う。ここでは図 17(a)に示すように, 工具を主と して渦巻き（spiral）状に送ることでワークピース上面を円形に研削する，送り速度（Feed speed）は，図 17(b)に 示すように工具が渦巻きの円周状に進む方向（Circumferential direction）の速度である．研削部の深さと幅を増加 させるため, 工具は図 17(b)に示す長手方向（Longitudinal direction）と半径方向（Radial direction）にも送られる. 実験条件を表 3 に示す. 長手方向の送り深さ (Longitudinal feed depth) および半径方向の送り深さ (Radial feed depth)

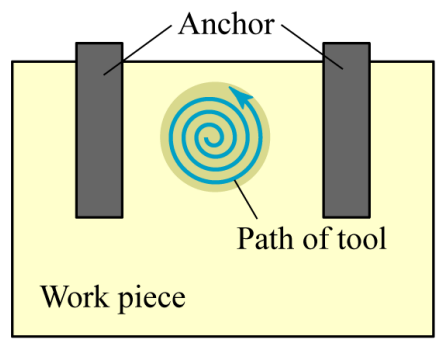

(a)

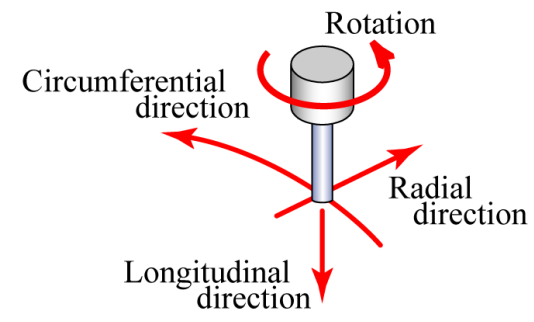

(b)

Fig.17 (a) Sketch of surface grinding and (b) motion of grinding tool.

Table 3 Surface grinding tests using a cylindrical tool with a diameter of $10 \mathrm{~mm}$.

\begin{tabular}{|c|c|c|c|c|c|}
\hline Test & $\begin{array}{l}\text { Longitudinal } \\
\text { feed depth } \\
(\mathrm{mm} / \text { circle) }\end{array}$ & $\begin{array}{c}\text { Radial Feed } \\
\text { depth } \\
(\mathrm{mm} / \text { circle) }\end{array}$ & $\begin{array}{l}\text { Rotational } \\
\text { speed (rpm) }\end{array}$ & $\begin{array}{l}\text { Feed speed } \\
(\mathrm{mm} / \mathrm{min})\end{array}$ & $\begin{array}{l}\text { Numbers of } \\
\text { spiral circle }\end{array}$ \\
\hline 7 & \multirow{7}{*}{0.05} & \multirow{9}{*}{0.25} & \multirow{9}{*}{6000} & 400 & \multirow{6}{*}{100} \\
\hline 8 & & & & 500 & \\
\hline 9 & & & & 600 & \\
\hline 10 & & & & 700 & \\
\hline 11 & & & & 800 & \\
\hline 12 & & & & 900 & \\
\hline 13 & & & & 1000 & \multirow{2}{*}{50} \\
\hline 14 & 0.10 & & & \multirow{2}{*}{500} & \\
\hline 15 & 0.15 & & & & 4 \\
\hline
\end{tabular}

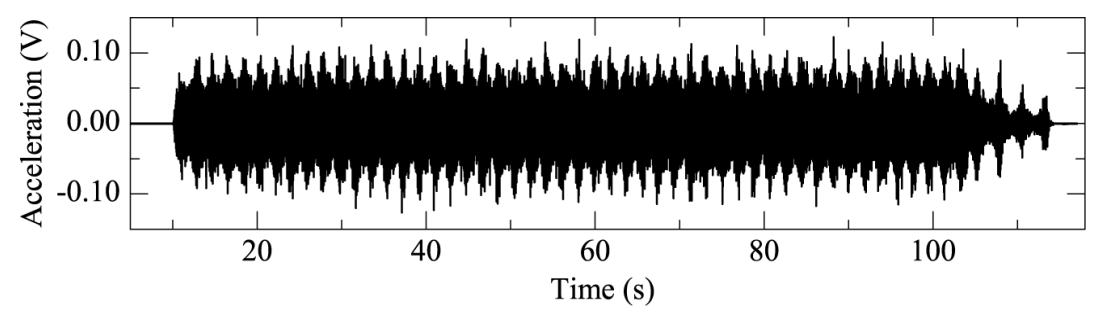

Fig.18 Acceleration during surface grinding in test 14. 


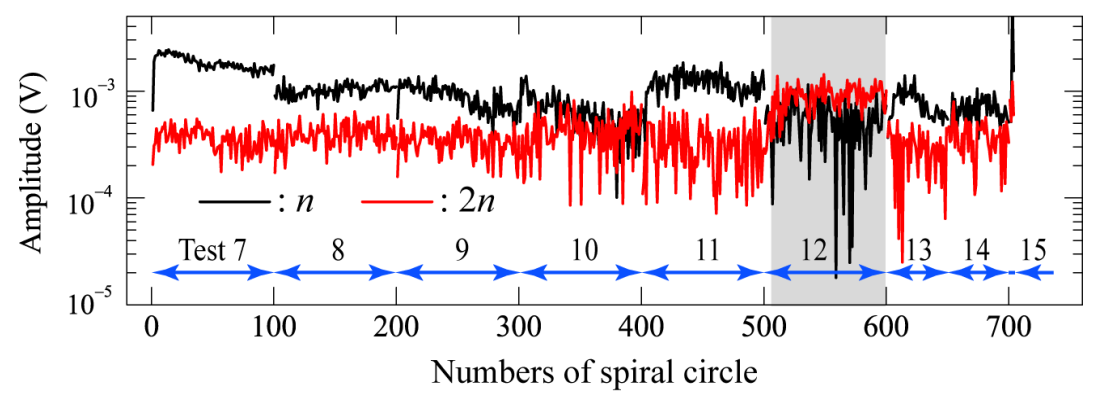

Fig.19 Transition of frequency components of $n$ and $2 n$ in amplitude modulation of acceleration during surface grinding.

は，それぞれ工具が渦巻き方向に 1 周動くにつれ長手方向および半径方向に送られる量である. 表 3 の条件も通 常より送り速度が速い加速試験としての条件である. 工具が破損するまでに行った実験は 9 回であり，それぞれ 実験 7〜15 と呼ぶ. 実験 15 の 4 周目で火花を伴い工具が破損した. 図 4 と同様, 固定具に取り付けた加速度ピッ クアップにより測定した振動加速度を対象とする. 振動加速度の例として, 破損直前の実験 14 において測定した 加速度を図 18 に示寸. 加速度波形の振幅にはうなりが観測され，1 つのうなりが研削工具の渦巻き動作 1 周分に 相当する. 最終の 4 周分の加速度振幅が徐々に小さくなったのは，送り深さを徐々に停止させたことによる．そ の他の部分の加速度振幅には研削行程の進行にともなう変化はほとんど見られない. 工具が破損した実験 15 にお いても，加速度振幅が増加するのは破損した周回のみであることを確認しており，ここでの実験では振幅の大き さから工具のモニタリングはできない.

これらの振動加速度について，研削工具の渦巻き動作 1 周分ごとの部分波形を対象とし，それぞれの振幅変調 の周波数成分を調べた. 工具回転数成分 $n=100 \mathrm{~Hz}(6000 \mathrm{rpm})$ とその倍数成分を詳細に調べた結果，加工の進 行に伴い有意な変化を示寸成分は $n$ と $2 n$ であることがわかった．これは 3.2 節の実験 1 ～ 3 と同様である. ここ で用いた工具は, 径が異なるものの 3.2 節と同種で端部が分かれていないため, この結果は妥当であるといえる. 結果を図 19 に示寸. 横軸は渦巻き運動の周回数であり実験 7〜15 について通し番号で示している. 周回数の 1 から 600 までは，100ごとにそれぞれ実験 7〜12 に相当し，周回 601〜 650 および 651〜 700 がそれぞれ実験 13 お よび 14, 周回 701〜704 が実験 15 に相当する. 図 19 から, 実験 7 開始からしばらく $n$ 成分が大きな值を示し, 研削を進めるにつれ徐々に低下寸る. 実験 10 の後半部で $n$ と $2 n$ 成分がほぼ同程度の大きさになるが，実験 11 で再び $n$ 成分が大きくなっている. さらに実験 12 になると, $n$ 成分が低下するとともに, $2 n$ 成分が急激に増大寸 る. これらの観察から, 実験 10 の後半くらいから, 工具状態に損傷につながる変化が起き始めたと推測できる. その後, 実験 13,14 で再度 $n$ 成分と $2 n$ 成分の大きさが逆転するが，実験 15 開始直後に工具は破損した. 図 19 の結果は, 実験 12 で $2 n$ 成分が $n$ 成分より大きくなった後, 実験 13,14 において 100 周程度の加工に耐えている ものの, 概ね図 10 の結果と類似している. 再度実験を行ってみても同様の結果が得られた. 実験 1〜3 と異なり, $2 n$ が $n$ より大きくなった後, 再びそれらの大きさが逆転して 100 周程度の加工できた理由は現時点で不明である が, 工具破損の少し前に $2 n$ 成分が増加して $n$ 成分と大きさが逆転寸ることは共通の現象である. したがって, 上 面研削においても $n$ および $2 n$ 成分に着目したモニタリングと, それらの成分の相対的な大きさの比較が, 破損前 の工具交換の指標として利用できるといえる.

\section{$3 \cdot 5$ 再現性と回転数の倍数成分}

$3 \cdot 2$ から $3 \cdot 4$ 節に示した実験は研削条件を変更して複数回行った. 工具破損に至る研削行程の回数が異なる ものの，定性的には概ね同様の結果を得た．才なわち，端部が分割されていない工具では， $n$ と $2 n$ 成分の相対的 な関係が，端部が 6 ブロックに分かれた工具では， $n$ と $6 n$ 成分の相対的な関係が，工具破損に近い状態で逆転す る結果を得た. したがって, 本研究で提案した振動加速度の振幅変調に着目するセラミック研削工具のモニタリ ングは，十分な再現性をもち有効な手法であると言える.

工具破損は，今回行った加速試験だけでなく，通常研削でも一力所の損傷が急激に大きくなって発生すること が現場での多くの実例を通じてわかっている. そのため, 破損が近い工具は図 11(c)のような状態にあると思われ， この状態で発生する $2 n$ 成分によって工具破損が近づいていると予測できる. したがって, 通常研削でも上述の $n$ 
と $2 n$ 成分の関係（端部が 6 ブロックに分かれた工具では $n$ と $6 n$ 成分の関係）が，工具破損に近い状態では重要 であると思われる. 一方, 加速試験よりゆっくりと破損に至る通常研削では, 工具破損に直接関連しないものの, 研削プロセスの中で工具の複数箇所に砥粒の脱落が生じ， $3 n, 4 n$ のような成分が比較的明確に発生することも考 えられる. 今回の実験では $n, 2 n, 6 n$ 以外の成分は工具損傷に関寸る有意な情報を示さなかったが，通常研削では 工具状態に関わる何らかの情報を与える可能性もある。この点は, 通常研削による実験の実施とともに今後の課 題としたい.

\section{4. 結}

(1) セラミックの研削加工中の振動加速度に着目し, 振動加速度の振幅変調を利用した研削工具のモニタリン グ手法を提案した.

（2）アルミナセラミックを連続的に研削する実験を行い，提案した手法を適用した．振動加速度そのものの周 波数解析ではモニタリングに有効な情報は得られなかった. 一方, 振動加速度の振幅变調の周波数解析では, 研 削工具の回転数とその倍数成分を明確に得ることができた. 回転数成分とその倍数成分の大きさの相対的な関係 から研削工具状態がモニタリングでき，工具損傷の予測に有効であることがわかった.

(3) モニタリングに有効な振幅変調の周波数成分は，工具形状に依存することがわかった．端部がブロックに 分割された工具では, 工具回転数成分とブロック数 $\times$ 回転数成分が重要であり, それ以外の工具では, 回転数と その 2 倍成分が重要であることがわかった.

（4）測定した振動加速度の振動特性は測定位置による差異がほとんどなく，どの振動加速度もモニタリングに 対して有効であった．提案した手法は測定位置の自由度が大きく，この点でも優れていることがわかった.

本研究は, 九州大学ーシュタインバイスジャパントランスファーセンター仲介の研究プロジェクトとして, 有 限会社小谷工業所との間で行われた。関係各位に謝意を表す。

\section{文献}

(1) Dornfeld D., "Application of Acoustic Emission Techniques in Manufacturing", NDT\&E International, Vol.25, No.6, (1992), pp. 259-269.

(2) Hwang T.W., Whitenton E.P., Hsu N.N., Blessing G.V. and Evans C.J., "Acoustic Emission Monitoring of High Speed Grinding of Silicon Nitride", Ultrasonics, Vol.38, (2000), pp. 614-619.

(3) Mokbela A. A. and Maksoud T.M.A., "Monitoring of the Condition of Diamond Grinding Wheels Using Acoustic Emission Technique", Journal of Materials Processing Technology, Vol.101, (2000), pp. 292-297.

(4) Liao T. W., Hua G., Qu J. and Blau P. J., "Grinding Wheel Condition Monitoring with Hidden Markov Model-Based Clustering Methods”, Machining Science and Technology, Vol.10, No.4, (2006), pp. 511-538.

(5) Liao T. W., Ting C-F., Qu J. and Blau P. J., "A wavelet-Based Methodology for Grinding Wheel Condition Monitoring", International Journal of Machine Tools \& Manufacture, Vol.47, (2007), pp. 580-592.

(6) Liao T. W., Tang F-M., Qu J. and Blau P. J., Grinding Wheel Condition Monitoring with Boosted Minimum Distance Classifiers", Mechanical Systems and Signal Processing, Vol.22, (2008), pp. 217-232.

(7) Tönshoff H. K., Friemuth T. and Becker J. C., "Process Monitoring in Grinding”, Annals of the CIRP, Vol.51, No.2, (2002), pp. 551-571.

(8) Hosokawa A., Mashimo K., Yamada K. and Ueda T., "Evaluation for Grinding Wheel Surface by Means of Grinding Sound Discrimination", JSME International Journal Series C, Vol.47, No.1, (2004), pp. 52-58.

(9) Furutani K., Ohguro N., Hieu N. T. and Nakamura T., "In-Process Measurement of Topography Change of Grinding Wheel by Using Hydrodynamic Pressure”, International Journal of Machine Tools \& Manufacture, Vol.42, (2002), pp. 1447-1453.

(10) Orhan S., Er A. O., Camuşcu N. and Aslan E., "Tool Wear Evaluation by Vibration Analysis During End Milling of AISI D3 Cold Work Tool Steel with 35 HRC Hardness", NDT\&E International, Vol.40, (2007), pp. 121-126. 
(11) Aliustaoglu C., Ertunc H. M. and Ocak H., "Tool Wear Condition Monitoring Using a Sensor Fusion Model Based on Fuzzy Inference System”, Mechanical Systems and Signal Processing, Vol.23, (2009), pp. 539-546.

(12) Lezanski P., “An Intelligent System for Grinding Wheel Condition Monitoring”, Journal of Materials Processing Technology, Vol.109, (2001), pp. 258-263.

(13) Liao T. W., Li K., McSpadden S. B. Jr. and O' Rourke L. J., "Wear of Diamond Wheels in Creep-Feed Grinding of Ceramic Materials I. Mechanism", Wear, Vol.211, (1997), pp. 94-103.

(14) Li K., Liao T. W., O' Rourke L. J. and McSpadden S. B. Jr., "Wear of Diamond Wheels in Creep-Feed Grinding of Ceramic Materials II. Effects on Process Responses and Strength”, Wear, Vol.211, (1997), pp. 104-112.

(15) 星鐵太郎著, 機械加工の振動解析，1版(1990), pp.3-49，工業調査会.

(16) Bracewell R.N., The Fourier Transform and its Application (2000), p. 359, McGraw-Hill. 